$\underline{\text { Obituary }}$

\title{
Dr. Stella Gertrude de Silva
}

\section{Consultant Paediatrician and Editor Emeritus, Sri Lanka Journal of Child Health}

Sri Lanka Journal of Child Health, 2012; 41(2): 104-105

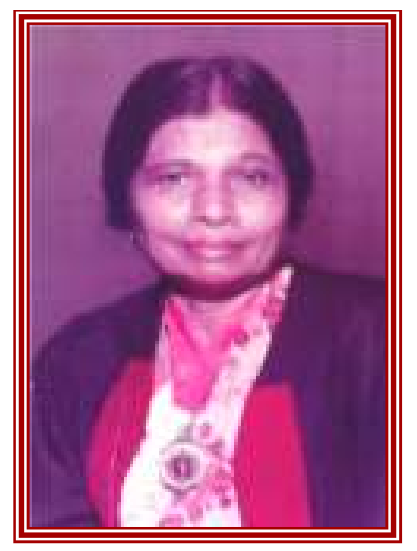

The Sri Lanka College of Paediatricians, together with the Sri Lanka Journal of Child Health wishes to place on record, with utmost sorrow, intolerable grief and a profound sense of loss, the demise of its Editor Emeritus, Dr. Stella Gertrude de Silva. She left us forever on the $12^{\text {th }}$ of April 2012, at the age of 93 .

As a practising paediatrician, she strode the world of paediatrics in our country like an indefatigable Trojan and a matchless colossus. Her academic brilliance, attention to detail, splendid diagnostic skills and unwavering commitment to excellence in anything that she touched, were indeed legendary. There are several generations of the populace of Sri Lanka who have reaped incomparable diagnostic and therapeutic benefits from her wonderful healing hands. She gave of her very best to all, irrespective of caste, creed, religion or wealth. As for her work ethic, she once said ${ }^{1}$ (quote) "Dedication is most important. Also sacrifice. Unless you are going to work hard with dedication and no thought of your leisure and money, it is useless becoming a doctor. Earning money is important, but not the most. Seeing an ill patient getting well is what is most important" (unquote). These were her splendid guiding principles in a profession that has a reputation as the noblest of them all and that quotation epitomises her life as a paediatrician. She was an exacting taskmaster in an unremitting pursuit towards providing the best possible care for her little patients.

Dr. Stella de Silva was a member of the extended academic arm of The Faculty of Medicine, University of Colombo. In that position, she was responsible for teaching paediatric medicine to

countless numbers of medical students. She also contributed in no small measure to the development and enhancement of paediatrics right throughout the country during her tenure of office as a Senior Paediatrician at The Lady Ridgeway Hospital for Children of the Ministry of Health in Sri Lanka. Following her retirement from the National Health Service in 1973 and after a sojourn in private consultation practice, she set up the Department of Paediatrics of the North Colombo Medical College in 1985 and was the Founder Professor of Paediatrics in that institution. Several legions of medical students benefitted from her vast experience in that endeavour. She had that glorious gift of being able to teach in a way that rationalised the entire practice of paediatrics. Doctors in Sri Lanka, who have been exposed to her memorable teaching sessions, would vouch for the fact that whatever they learned from such a scholar of the art, they would remember for ever more.

She gave the very best of her time and dedication to the Sri Lanka Paediatric Association, which later became the Sri Lanka College of Paediatricians. She was the president of this august institution in $1962 / 1963$. Stella, as she was ever so affectionately referred to by very many, was well acknowledged for her performance par excellence in the field of editorial work for The Sri Lanka Journal of Child Health, the official publication of the Sri Lanka College of Paediatricians. As chronicled elsewhere $^{2}$, she started her editorial duties with the Ceylon Journal of Child Health, Volume 4, in 1967, just 4 years after the inception of the journal. It was then an annual publication and she saw to it that it was published uninterrupted. Together with the writer, who was appointed as her Co-Editor in the year 2000, she successfully managed to change the title of the journal to that of Sri Lanka Journal of Child Health and converted it from an annual to a quarterly publication. Working with her in the journal was quite an illuminating experience. She was indeed the best of them all. Her unending quest for excellence in the publication was an abject lesson to lesser mortals like the writer himself.

Dr. Stella de Silva decided to give up the reins of managing the journal in 2003 and the Sri Lanka College of Paediatricians was delighted to appoint her as its very first Editor Emeritus. During the last 12 years the journal has gained in stature and is now the principal academic journal of child health 
in the country. It is available in print and free text electronic formats. Stella's work as an editor for 36 long years, a World Record by any stretch of imagination, was the cornerstone on which the progress of the journal was based. To the best of our knowledge, no other person in the world has had the distinction of guiding the destiny of a medical journal for such a long time.

From a personal perspective, I have had the good fortune and the singular dispensation to have been her student, a junior colleague and a fellow Joint Editor. She was my mentor in every sense of the word. She played a major role, quite early in my career, in even teaching me the basics of proper scientific writing ${ }^{2}$. Indeed, many are the fantastic lessons that I learnt at the feet of the guru. She taught us all, how exactly one must run an academic journal and how one must conscientiously and tirelessly "aim for gold" in such a publication. Her razor sharp and perceptive mind was able to grasp and resolve problems expeditiously, as and when they arose. In the truest sense of the phrase, I feel her irreplaceable loss, perhaps more than anyone else.

There was, and there could ever have been, only one Stella. They have thrown away the mould in which she was made. She was a resplendent jewel of a lady with many a different facet to her personality and she dazzled in all her activities, just like a diamond that radiates the colours of the rainbow as light falls on it. This wonderful human being left us just the same way she lived, quite unpretentiously. She peacefully faded off over just a few days. However, the fable that was Stella would live forever in the hearts and minds of all Sri Lankans and her deeds, together with her unmatched profile, would be etched in gold for posterity in the annals of the history of paediatrics in Sri Lanka.
Dr. Stella de Silva was a devout Buddhist and according to the philosophy of the religion that she believed in, I have no doubt that the merit that was accrued from her selfless service to the children of Sri Lanka would assist in shortening her journey in Samsára.

May she attain the supreme bliss of Nirvāna.

\section{References}

1. Available from: $<$ http://www.island.1k/2008/06/08/leisure1.htm l> Accessed on 07-05-2012

2. The order changeth: A tribute to a superlative editor. Sri Lanka Journal of Child Health 2003; 32:1-3

\section{B J C Perera}

Joint Editor 